\title{
John Calvin's Institutes of the Christian Reli- gion, by Bruce Gordon
}

Lives of Great Religious Books | Princeton: Princeton University Press, 20I6 | 304 pages | ISBN: 978-I-400-88050-8 (hardcover) $\$ 27.95$

Bruce Gordon is a good writer and knows Calvin very well. This combination makes his John Calvin's Institutes of the Christian Religion, which appears in the Lives of Great Religious Books series from Prince-

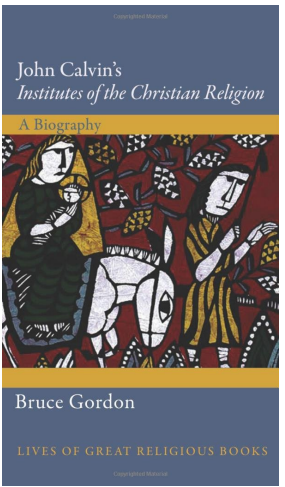
ton University Press, a superb read. It is at once easy to digest and deeply satisfying.

Though it is not uncommon for a reader to pass over an introduction in order to get to the more meaty part of a book, I would recommend against this here. Gordon's introduction, "Remembering a Man and His Book," with which he begins his treatment of his subject, is sharp and does excellent spade work trying to expose and deal with various assumptions and myths 
that have grown up around Calvin and his most-famous tome. When Gordon writes that Calvin "has often been abducted by individuals and groups seeking to use his name for positions he could never have held" the present reviewer wanted to applaud. The sentiment is absolutely true and finds numerous examples arising if proof of the point is needed. Gordon's sentence has appended to it, "such as the modern ideas of biblical inerrancy" which is sure to ruffle the feathers of some of his readers, but seems in my judgment not only to be accurate but also to demonstrate extraordinarily well one of the sub-texts that runs through Gordon's book, namely, the fact that Calvin is truly, really a man of his own time.

The introduction is followed by a fine chapter entitled, "A Book Emerges," in which Gordon seeks to set in context both the publishing of Calvin's first edition of the Institutes in I 536 and also the rather ordinary character of the work-ordinary in the sense that Calvin's first Institutio Christianae Religionis was one of a myriad of books being published at this time which sought to minister to the "Catholic" (i.e., universal) Christian community of the sixteenth century. Gordon examines carefully the origins of Calvin's book, looking at the Frenchman's character as an exile from his native France, looking briefly at Calvin's birth and youth, examining themes such as the doctrine of election, Calvin's qualities as an author, and the early French editions of the Institutes.

The next chapter looks at the I 559 edition of the Institutes, which is by common consent regarded as the definitive edition. The bulk of Gordon's coverage in this short chapter focuses on Calvin's approach to knowledge and the nuanced complexity of his handling of this subject.

With chapter 3, Gordon begins working his way through the centuries which followed Calvin's death. He commences with that death, also mentioning (as he does throughout the volume) the generally-unfavorable attitude that greets Calvin wherever he goes: Calvin the monster; Calvin the harsh, unfeeling systematician. The list is endless, and Gordon does an excellent job of addressing these misconceptions without appearing defensive. He does, moreover, an admirable job of gently setting the record straight on the caricatures that have been applied to Calvin from his own day (with individuals like Jerome Bolsec being one of the early offenders in this regard) to the twenty-first century.

What Gordon produces in chapters 3-I 2 is a handful of really outstanding chapters covering the reception of the Institutes during certain periods of history or geographical locations. There is the Dutch Calvin; the American Calvin; the Calvin who features in the debates between Karl Barth and 
Emil Brunner; Calvin the prophet of modernity; the South African Calvin associated with apartheid; and so forth. Gordon handles all of these deftly.

As may be apparent to the reader of this review, it may well be the case that some readers will, when picking up Gordon's book, be introduced to individuals, themes, and disputes with which they are unfamiliar. But this should not scare them away from Gordon's treatment which gently eases the reader into these introductions, as a perfect host does a late-arriving dinner guest. Gordon knows his subject very well-well enough to wear his scholarship lightly.

Throughout the work one is permitted to reflect on themes and ideas in a way that is both pleasant and thought-provoking. Even humorous comments provide this entertainment. In chapter I 2, "Contemporary Voices," for instance, Gordon notes that Calvin has recently been called the "Barack Obama of the sixteenth century." Gordon also clearly feels free to reflect in a broader way (and in my judgment, delightful way) on the presence of Calvin and his Institutes in the modern world. He, rightly, contends that in many respects both "have never been more present" (I99). Gordon briefly discusses feminist readers of the Institutes, great literary works that reflect on the Institutes and themes that arise out of it, and other topics currently running through the veins of modernity. Thus, the work is a fabulous read: enjoyable, scholarly, and accessible. For someone looking to deepen her knowledge of Calvin's magnum opus, Gordon's volume provides the perfect solution.

Jon Balserak University of Bristol 